personal speculations about patients and possible diagnoses that may be taken out of context. Some abbreviations, such as using "SOB" to stand for "shortness of breath," could come across as a slur to the untrained eye.

"I find myself writing my notes somewhat differently, but not very differently," Delbanco says. "I use fewer technical words, I'll add some educational material as I go and I'll think more consciously of what the patient will experience reading the note."

Putting more thought into a note doesn't take more time, he adds. "I find it doesn't take one second longer. It's just a different way of doing business."
Patients are more resourceful than their doctors may suspect, Hallissey says. "If I read some medical terminology I don't understand, I go on Google or some search engine and find the definition. I know how busy physicians are today and time is important to them."

Another advantage for patients, Meltsner says, is that some doctors can be clearer in their notes than they are face to face. Doctor's concerns over political correctness can lead them to be less than candid in conversations (CMAJ 2010. DOI:10.1503 /cmaj.109-3308).

But the clarity that doctors' notes can offer may be a double-edged sword when it comes to medical errors. Some physicians are concerned that opening their notes to patients may in turn open themselves to malpractice suits, says Delbanco.

Meltsner, though, argues that transparency is just as likely to quell litigation as to provoke it. "The notes could reveal just as many things the doctor did right that the patient may not have known about," he says.

It's expected that preliminary findings of the study will be published early in 2011. The project will conclude next summer. - Lauren Vogel, CMAJ

\title{
Obama's health law at six months: survival is not assured
}

\section{Previously published at www.cmaj.ca}

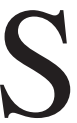
ix months after President Barack Obama's landmark health care law, free preventive care is taking effect for millions more Americans, children have new insurance protections and seniors are getting more help for their drug bills, all down payments on an unfolding and historic transformation of the system.

So where's the love?

The hard-won reforms remain a hard sell for the public. They are proving to be fodder, too, for Republicans who have "Obamacare" in their crosshairs heading into fall elections that could change the balance of power in Washington - and the course of health care yet again.

The benefits of the new law are taking effect in myriad ways, some more visible than others. As of Sept. 23, insurance companies were no longer allowed to set lifetime limits on benefits in new or renewing plans. They were also prohibited from denying coverage to sick children, another widely despised practice. They also had to let children younger than 26 years of age remain on their parents' employerbased health plans in most cases.

Preventive treatment also got a boost at the same time. An estimated 41 million people gained free access to a range of preventive services from
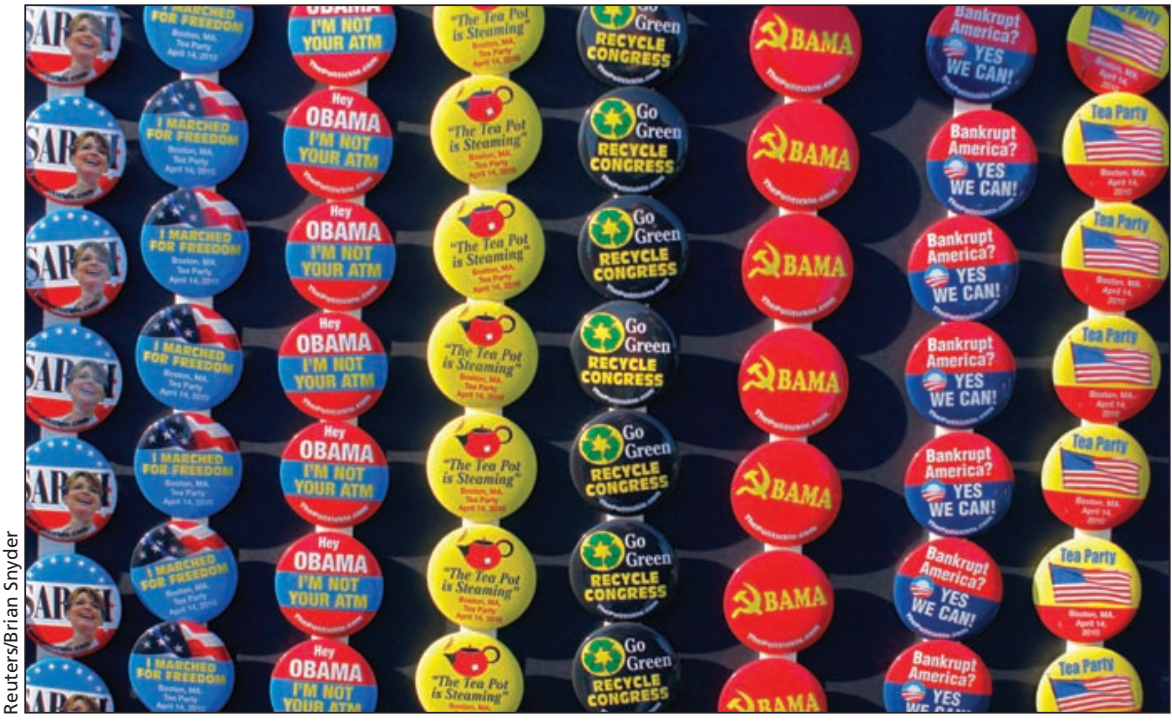

An array of forces hope to undermine United States President Barack Obama's Patient Protection and Affordable Care Act.

weight and smoking cessation counseling to vaccines, well-baby care and routine screenings for cancer and other disease. Federal money is pouring into community health centers, electronic record-keeping in doctors' offices, and scholarships and debt relief for health professionals in needy areas.

Few dispute the value of such steps. The problem remains as it has always been: a suspicion of growing federal power in health care and people's lives.

The reforms are anchored by a looming reality that splits the country:
Health insurance will become mandatory under the plan in 2014 (enforced by the much-unloved Internal Revenue Service). People will need to buy it just as drivers need auto insurance. And only with universal coverage - the tens of millions more paying customers it will bring - can the private insurance market live under the new rules and can taxpayers sustain an overhaul costing an estimated US\$1 trillion over a decade.

It's that mandate Republicans have sworn to defeat. 
Their rhetoric is bold, at times hyperventilating.

"President Obama dismantled the finest medical system in the world and replaced it with a failed socialist model," Representative Steve King, a Republican congressman from Iowa, says on the party-sponsored website America Speaking Out. "The president nationalized your skin and everything inside it, and he enlarged the scope of the IRS by granting the agency the power to confiscate the assets of Americans who refuse to submit to the nanny state."

Never mind that people still own their innards. Lawmakers steered well clear of nationalized medicine or almost anything resembling the Canadian system in adopting reforms that keep the private insurance market at the core of health care.

Every mainstream measure of public opinion finds unease, at best, with the law. And in a test at the ballot box last month, more than $70 \%$ of voters in Missouri backed a state initiative opposing the requirement to carry health insurance. The nonbinding vote demonstrated the political risks in a finger-to-the-wind presidential election battleground state.

So far, Obama's overhaul has not made people more secure about their own care, according to recent surveys of health-care consumer confidence by the Robert Wood Johnson Foundation. Neither has it undermined people's outlook.

The surveys found that consumer confidence about the health care system rose after enactment of the law, then slid back to 2009 levels. It's simply too early for most people to see change in their own experience, says Lynn Blewitt, who analysed the surveys for the foundation as director of the State Health Access Data Assistance Center at the University of Minnesota.

"Americans have been remarkably even-keeled in their attitudes about health care," she says. "Mostly we think most people's experience with the health care system is relatively positive. It's important to remember that most Americans have health insurance coverage. For those who don't have it, the bill creates opportunities for them" in coming years.

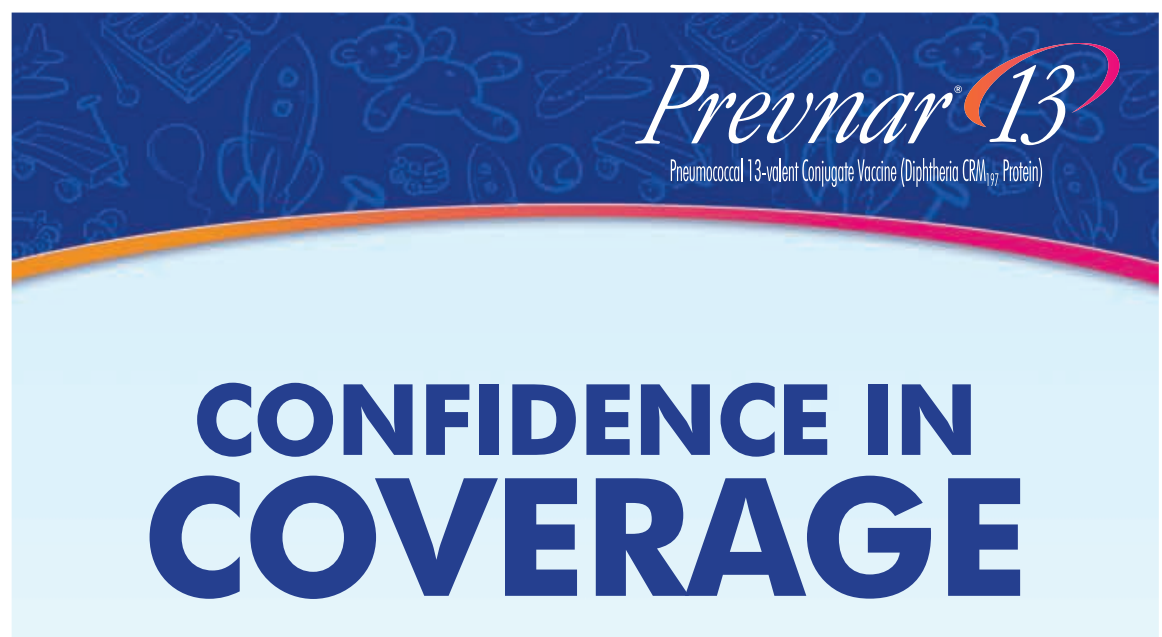

\section{Providing the broadest coverage of S. pneumoniae serotypes indicated in a pneumococcal conjugate vaccine $e^{n, 2,3}$}

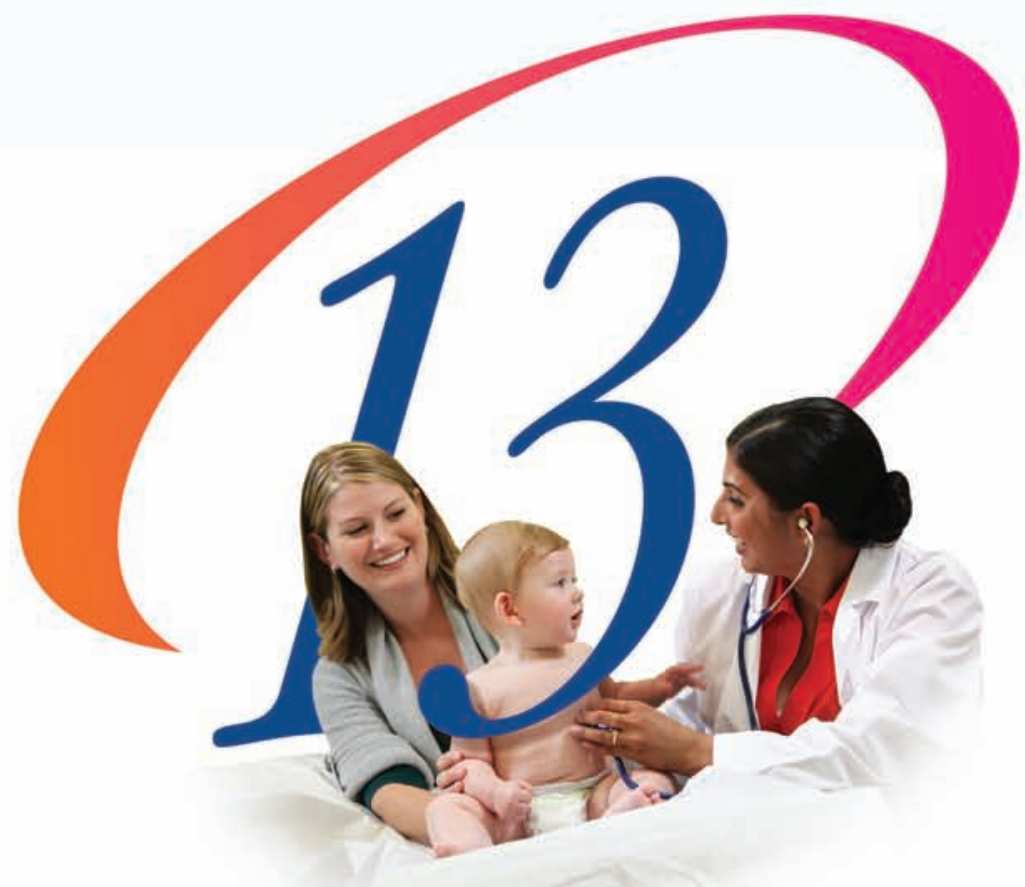

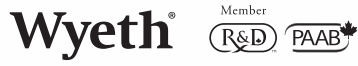

(c) 2010 Wyeth Canada
Montréal, Canada H4R 1J6 
The lesson for nervous policymakers, she says, could be: "Hang on, things are changing over time."

But it took an epic political struggle to pass the most ambitious social legislation in decades and now, a month from congressional elections, Republicans are making a strong play for control of the House of Representatives and appear likely to make gains in the Senate. Tea party activists scored key victories in primary races, edging the Republican's roster of candidates even farther to the right.

To be sure, unraveling the massive Patient Protection and Affordable Care Act is a tall order. For all of their calls to "repeal and replace" it, Republicans know that if they somehow passed legislation to strike the law or parts of it, Obama would exercise a veto. But Congress controls federal spending and that's where foes can create roadblocks by holding back money.
"Without the president, we can't repeal it," concedes Senator Mitch McConnell of Kentucky, the Republican Senate leader. "But we can go after portions of it aggressively."

The fight goes on in court, too. Twenty states have challenged the insurance mandate in what supporters of the law at first dismissed as a desperate gambit to skirt the legislative process (CMAJ 2010;DOI:10.1503 /cmaj.109-3223). But the first court to take it up, in Virginia, refused the government's request to dismiss the suit.

Meantime Washington is busily writing cheques in a series of stopgap benefits until the full weight of the reforms kicks in.

Nearly four million elderly or disabled people on US Medicare are now getting one-time payment of US $\$ 250$ apiece to help pay drug costs not covered under the plan. The government is spending US $\$ 5$ billion to help employ- ers offer affordable coverage for early retirees under 65 - too young for Medicare. The subsidy vastly trims health care costs for that vulnerable segment of the population until the meatiest reforms are in place, mostly 2014. Then, new competitive insurance markets will exist, no one of any age will risk losing coverage or being denied insurance by being sick, hefty federal aid for affordable policies will flood to citizens and businesses, and older people will no longer pay crushingly higher premiums than the young.

People who have yet to see the pluses and minuses of the new ways are almost certain to by then. That's if the law makes it to 2014. Two other key dates come first: the elections of 2010 and 2012, both shaping Congress and the second deciding the presidency. Cal Woodward, Washington DC

DOI:10.1503/cmaj.109-3666

\section{United States to compel physicians to make "meaningful use" of electronic health records}

Previously published at www.cmaj.ca

$\mathrm{T}$ he contrast is startling. The United States government recently adopted regulations that will compel — and generously pay - American physicians to make "meaningful use" of electronic health records (EHRs).

But in Canada, the financial incentives aren't as lucrative and no doctor is under obligation to actually use EHRs, even if they use government monies to purchase the technologies. As a consequence, EHR uptake remains low despite programs such as the province of Ontario's \$386-million EHR incentive program.

Under economic recovery legislation passed in 2009, the US government plans to spend as much as US\$27 billion in EHR incentive payments to physicians over 10 years commencing in May, 2011. Doctors will be eligible to receive as much as US\$63000, and hospitals may also receive millions of dollars for using federally-certified EHRs.

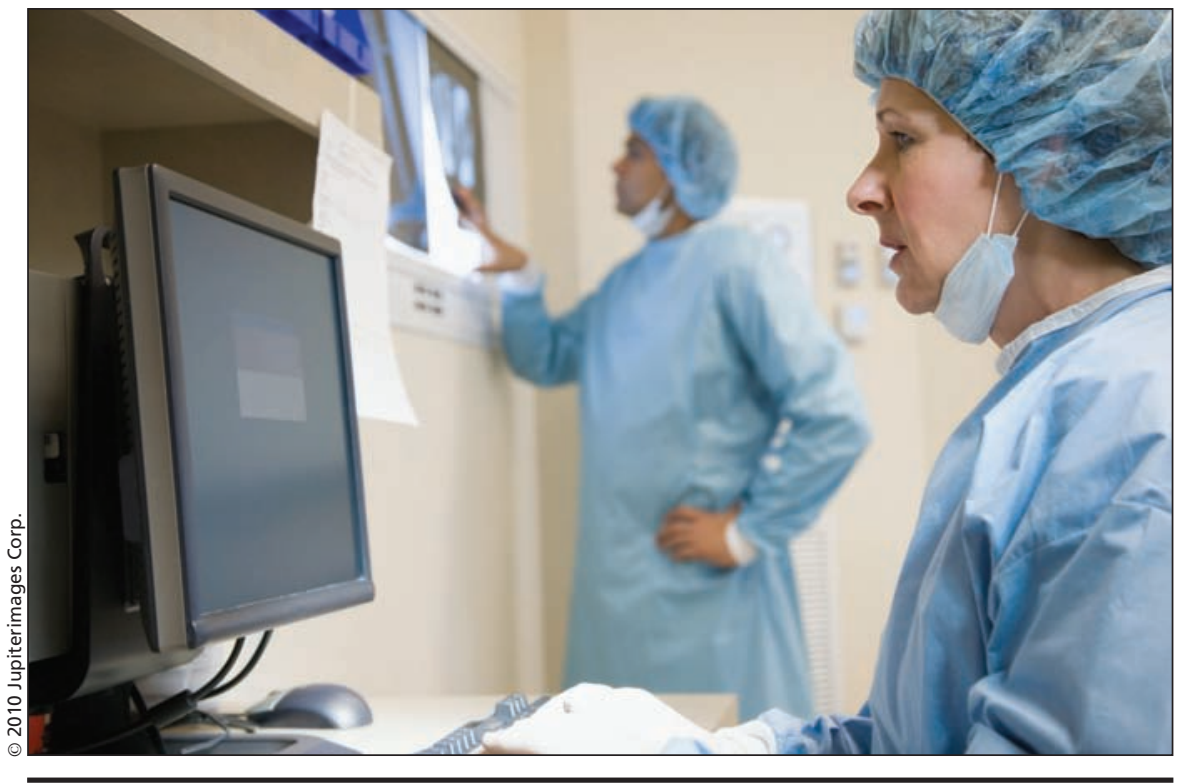

American doctors will receive as much as US\$63 000 to purchase and use federallycertified electronic health record technologies.

The US regulations, published July 28 , are designed to ensure that the government's investment leads to "meaningful use" and rapid adoption of EHRs (http://edocket.access.gpo.gov/2010/pdf /2010-17207.pdf).

To help forge an electronic health revolution, the US regulations set out a 